\title{
Fallout hits research
}

\section{Munich}

OpPosition to nuclear power, a cause embraced by citizens' initiatives and splinter parties a decade ago, has begun to take over the political mainstream in West Germany, with potentially dire consequences for scientific research. In a decision that is certain to have broader implications, West Berlin Mayor Walter Momper, a Social Democrat, last week surprisingly withdrew his support for a 10MW research reactor located at the HahnMeitner Institute (HMI). The move endangers the existence of HMI, one of 13 national laboratories in West Germany.

Momper had originally promised to award a licence to the refurbished reactor by 31 July at the latest. But the environment minister in his coalition government, Michaele Schreyer of the Alternative Liste, refused to issue the licence because of the lack of permanent storage space for the radioactive waste produced by the reactor (see Nature 346, 405; 1990.) Alternative Liste is the local branch of the environmentalist Green Party.

After a majority vote on 7 August by the West Berlin Senate in favour of licensing the reactor, researchers had been expecting Momper to reverse Schreyer's decision somehow, for example by removing her jurisdiction over licensing. But such a move would have endangered the fragile West Berlin coalition, and elections are only three months away. Instead, Momper returned from holidays on 13 August with the surprising news that he had been at least partly convinced by Schreyer's arguments.

Momper then offered HMI two unappetizing options. If he found Schreyer's case against licensing the reactor "watertight", he said, there would be nothing more he could do, and it would be up to HMI to bring a lawsuit against Schreyer. If not, he would reopen the licensing procedure, which would probably require new public hearings and could not be concluded until after the forth-coming elections. In either case, it would take months, if not years, for the reactor to receive a licence.

The overhaul and upgrading of the reactor from 5 to $10 \mathrm{MW}$ was completed last year at a cost of DM170 million (about $\$ 110$ million). Most of the money came from the Research Ministry in Bonn, which pays 90 per cent of the operating costs of the national laboratories (Grossforschungseinrichtungen). The reactor is to be used as a neutron source for biology, medicine and chemistry as well as physics.

Tired of broken promises from Momper, West German Research Minister Heinz Riesenhuber (Christian Democrat) last week issued an ultimatum: license the reactor by 21 August, or Bonn will pull out of financing HMI. According to West Berlin Senate spokesman Werner Kolhoff, West Berlin is already overburdened by the costs of reunification and could not afford the DM100 million a year that would be required to keep HMI open if Bonn pulls out.

Some see Momper's and Riesenhuber's actions as gestures made solely to avoid losing face. As a prominent representative of a party that is officially against nuclear energy, Momper cannot afford to back the HMI reactor unless final waste storage is secured. And Riesenhuber, who has been threatening to pull out of HMI for months, cannot easily back down now.

On this view, HMI will have to be patient for a few months until all-German and allBerlin elections, both of which are scheduled for 2 December. After that, perhaps, the federal government will be able to force the licensing of the reactor in the case of a legal challenge, a possibility that comes about because of the murky legal status of West Berlin. For at least a few more weeks, it will remain under the jurisdiction of Allied occupying forces, not of Bonn.

But the patience of HMI is nearly at an end. Spokesman Thomas Robertson called the situation at HMI "miserable". HMI has lost one candidate for the open position of director and may well lose a second in the next few days. Researchers in unrelated fields such as solar cell development who are contemplating moving to HMI are bound to be influenced by the worries about the institute's future, says Robertson.

The turmoil at HMI occurs against a backdrop of rising opposition to nuclear power in West Germany. The Social Democrats (SPD), one of the two largest political parties, dropped their support of nuclear power in 1987 following the Chernobyl accident. SPD has won a series of elections in the Länder (states) which have given it a majority in the Bundesrat, the upper house of parliament. A victory by SPD in forth-coming national elections could turn the West German nuclear industry on its head, with an equally devastating if narrower impact on science. The problem may become especially acute at Garching, near Munich, where the Bavarian government has hesitated to replace an ageing research reactor at the Technical University of Munich because it feared a local backlash.

The dispute about the HMI reactor has already endangered Berlin's standing as an attractive site for research and industry. Both the heads of West German research organizations and the Chamber of Commerce and Industry of West Berlin have issued messages to that effect in recent weeks.

Steven Dickman

\section{MITI heads for inner space}

Tokyo

JAPAN's ever-ambitious Ministry of Inter national Trade and Industry (MITI) seems to have found in Steven Spielberg's film Inner Space, about a microsubmarine that ventures through human blood vessels, an idea for its next venture. At the end of this month, MITI's Agency of Industrial Science and Technology (AIST) will submit a budget request for $¥ 30$ million $(\$ 200,000)$ to launch a 'microrobot' project next year, with the aim of developing tiny robots for the internal medical treatment and repair of human beings. The robots will also be used for the maintenance and repair of nuclear power plants and may find applications in space.

Although the initial budget request is small, as is usually the case with MITI projects in their first year, MITI is planning to pour $¥ 25,000$ million ( $\$ 170$ million) into the microrobot project over the next ten years under AIST's 'Iarge-scale' (Ogata) industrial research programme.

The Ogata projects are among the biggest in AIST's repertoire, and there was stiff internal competition within MITI for selection of the one new project that can start next year. Furthermore, the proposed budget and project duration are unusually ambitious - Ogata projects typically run for seven years on budgets of about $¥ 15,000$ million.

Kenzo Inagaki, deputy director of MITI's industrial machinery division,

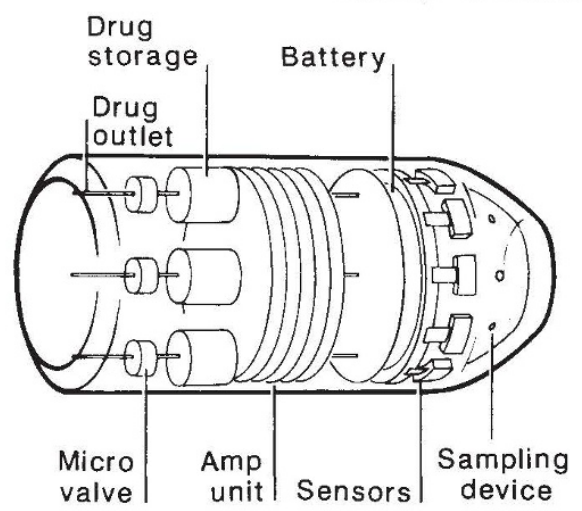

Getting smart: a sketch of MITI's projected 'pill'. No delivery dates have yet been announced

which helped to formulate the project, says that although MITI's draft proposal discusses microrobots manipulating cells, robots that travel through blood vessels à la Spielberg are "at least a hundred years off". But he thinks that robots of about a centimetre in size that can enter the stomach and intestine are feasible.

One idea is to develop a 'smart pill' that will be equipped with a sampling device and sensors in the nose cone (to detect, for example, $\mathrm{pH}$ and temperature), and a 
drug delivery system in the rear.

Several robot manufacturers, including FANUC and Fuji Electric Co., are expected to join the project, together with semiconductor manufacturers such as Hitachi, NEC and Toshiba. And Inagaki says that, although "officially" Ogata projects are totally financed by MITI, industry is expected to contribute "an additional 30 per cent or so".

The project was proposed by a MITI committee of industrialists and academics headed by Naomasa Nakajima of the department of mechanical engineering at Tokyo University. Another member of the committee is Isao Karube of the Research Center for Advanced Science and Technology of the same university, well known for his work on biosensors, such as blood glucose analysers.

Inagaki says that research in the field of micromachines is only about five years old and that the number of researchers worldwide with expertise is very limited. For this reason, MITI officials are hoping to make the project into a joint international effort. But they do not intend to approach potential foreign collaborators until details of the project are finalized

The project is an amalgamation of proposals and includes plans to develop microrobots for the maintenance and repair of nuclear power plants, chemical plants, gas and water pipes and aircraft engines. And MITI foresees a day when microrobots will be able to patrol the piping of nuclear power plants and carry out repairs "whenever an abnormality is detected", avoiding expensive shut-downs for maintenance and repair.

One likely addition to the project is the development of robots for use in space, already being investigated under another Ogata project.

MITI's budget proposal will no doubt be trimmed down in negotiations with the Ministry of Finance. And it remains to be seen if the Ministry of Health and Welfare will remain silent while MITI launches a project that delves deeply into the realms of medicine and drugs. But MITI will probably disguise and alter the project in such a way as to avoid objections.

\section{David Swinbanks}

\section{Heated argument in prospect}

\section{Sydney \& Boston}

CRITICISM of the US Army's programme to incinerate chemical weapons on Johnston Island in the Pacific has come from several quarters in recent weeks, even though the incineration programme is already fully operational and more US chemical weapons are on their way to the island from bases in Germany. The debate, both in the United States and in the South Pacific countries, has caused a split between environmentalists and arms control advocates, but now seems unlikely to affect the fate of the Johnston Island programme. Nevertheless, it may well have an impact on the long-term prospects for incineration as a way for the superpowers to dispose of their vast and ageing stockpiles of chemical weapons.

At a meeting of the South Pacific Forum, held earlier this month in the small Pacific nation of Vanuatu, some participants continued to criticize the US chemical weapons incineration plant on Johnston Island as "another example of the Pacific being used by major weaponsproducing states as an experimental area". Of the forum nations, only Australia and New Zealand supported the Johnston Atoll Chemical Agents Disposal System (JACADS), which began operation on 30 June (see Nature 346, 5; 5 July 1990). A communique released by the island nations opposing the plant complained about the "significant uncertainties and risks" posed by the project.

Nor were the forum participants reassured by three scientific reports presen- ted by Australia's Prime Minister, Bob Hawke, in support of US claims that the weapons destruction methods include adequate environmental safeguards. According to the US Department of Defense, workers at the JACADS incineration facility have already safely destroyed more than 800 artillery shells and some 2 tons of nerve agent. By now, Johnston Island, $1300 \mathrm{~km}$ southwest of Hawaii, has accumulated some 300,000 weapons ready for incineration, including mustard and nerve gas shells. Another 100,000 US shells consisting of 400 tons of Sarin and VX nerve gas are in transit from Clausen, West Germany.

The environmental advocacy group Greenpeace continues to be one of the most vocal opponents of JACADS, claiming that the high-temperature incineration process produces toxic bioaccumulative chemicals such as polychlorinated dioxins and furans. According to Paul Johnston, Greenpeace International spokesman on chemical weapons, there are four safer alternatives: chemical neutralization; photodegradation; electrochemical procedures and biodegradation.

These methods, Greenpeace argues, have the advantage over incineration that they would be done in closed systems, and would not "result in huge volumes of gases being pumped into the atmosphere". A recent Greenpeace technical review* of the JACADS programme reviewed the

* Greenpeace Review of Johnston Atoll Chemical Agent Disposal System (JACADS), July 9, 1990. prospects and current status of each of these alternative methods. Johnston says that these alternatives could be developed into working techniques within 18 months if the US Army were to conduct accelerated research on them.

But Trevor Findlay, senior research fellow at the Peace Research Centre of the Australian National University in Canberra, does not believe that the alternatives offered by Greenpeace are totally safe either. As with incineration, Findlay points out, all four proposed alternatives require the lethal chemical agents to be taken out of their shells. The possibility of spills and accidents, he says, poses a safety and environmental threat from almost any proposed method.

Now that US Defense Secretary Dick Cheney and congressional committees have agreed in principle to cancel the US binary chemical weapons modernization programme, arms control advocates in the United States are heartened by US actions and see JACADS as "a big step forward" in the effort to live up to an agreement, reached with the Soviet Union last spring, that at least 80 per cent of both superpowers' chemical stockpiles should be destroyed. Many other countries, even some Pacific nations, have supported the demilitarization effort despite the potential environmental threat posed by chemical weapon destruction.

Australia, for instance, has supported JACADS as part of a push towards an international chemical weapons treaty (Nature 341, 271; 1989). Unless it destroys its own stockpile, the United States is seen to be in no position to push other countries into signing a treaty.

But, environmentalists point out, even with the addition of the US chemical weapons from Germany, only some 7 per cent of the US stockpile will be destroyed at the Johnston Island facility. The Soviet Union's stockpile, none of which has yet been destroyed, is believed to be larger still. Thus the fate of most of the superpowers' chemical arsenals remains uncertain, and the environmental stakes are high. The Soviet's plans are unclear, although they too are working on incineration methods and are committed to collaborating with the United States in the weapons' destruction.

The remainder of the US chemical weapons arsenal is marked for incineration at eight domestic facilities, yet to be built.

Environmentalists say that they will fight the plan and push for more research into alternative methods. "Our fight at Johnston Island is not over yet and our serious concerns continue about the environmental damage caused by incineration", says US Greenpeace spokesperson Sebia Hawkins; "the larger fight in the United States is just beginning".

Tania Ewing \& Seth Shulman 